\title{
TECHNOLOGICAL AND FUNCTIONAL PROPERTIES OF LACTIC ACID BACTERIA: THE IMPORTANCE OF THESE MICROORGANISMS FOR FOOD
}

\section{Propriedades tecnológicas e funcionais de bactérias láticas: a importância destes microrganismos para alimentos}

\author{
Amanda de Souza Motta ${ }^{1 *}$, Melina da Silva Mesquita Gomes ${ }^{2}$
}

\begin{abstract}
Eacters of coccus or rods Gram-positive, catalase negative, non-sporulating, which produce lactic acid as the major end product during the fermentation of carbohydrates. When applied on food, provides beneficial effects to consumers through its functional and technological properties. With this the present review article, explore the potential application of lactic acid bacteria in food. The following genera are considered the principal lactic acid bacteria: Aerococcus, Carnobacterium, Enterococcus, Lactobacillus, Lactococcus, Leuconostoc, Oenococcus, Pediococcus, Streptococcus, Tetragenococcus, Vagococcus and Weissella. These cultures have been used as starter or adjunct cultures for the fermentation of foods and beverages due to their contributions to the sensorial characteristics of these products and by microbiological stability. Their probiotic properties have also been investigated. More recent studies by indigenous cultures have received increased attention in light of the search for isolated cultures of a given raw material and a certain region. These microorganisms are being investigated for its functional and technological potential that may be applied in product development with its own characteristics and designation of origin. Those properties will be discussed in the present review in order to highlight the performance of these bacteria and the high degree of control over the fermentation process and standardization of the final product. The use of autochthonous cultures will be considered due the increase of studies of new cultures of lactic acid bacteria isolated of milk and meat of distinct products.
\end{abstract}

1 Universidade Federal do Rio Grande do Sul(UFRGS), Avenida Paulo Gama, 110, Farroupilha, 90040-060, Porto Alegre, RS, Brasil. E-mail: amanda.motta@ufrgs.br

2 Universidade Federal de Pelotas (UFPEL), Pelotas, RS, Brasil.

* Autor para correspondência.

Recebido / Received: 18/02/2015

Aprovado / Approved: 20/08/2015 
Keywords: lactic acid bacteria; autochthonous culture; technological and functional property; antimicrobial activity; dairy products.

\section{RESUMO}

Bactérias produtoras de ácido láctico são um grupo de microrganismos com as características morfológicas de cocos ou bastonetes Gram-positivos, catalase negativos, não esporulantes, que produzem ácido láctico como o principal produto final durante a fermentação de hidratos de carbono. Quando aplicadas em alimentos, proporcionam efeitos benéficos para os consumidores através de suas propriedades funcionais e tecnológicas. Com isto o presente artigo de revisão objetiva explorar o potencial de aplicação de bactérias lácticas em alimentos. Os seguintes gêneros são considerados os principais produtores de ácido láctico: Aerococcus, Carnobacterium, Enterococcus, Lactobacillus, Lactococcus, Leuconostoc, Oenococcus, Pediococcus, Streptococcus, Tetragenococcus, Vagococcus e Weissella. Essas culturas têm sido usadas como culturas iniciadoras ou adjuntas para a fermentação de alimentos e bebidas, devido às suas contribuições para as características sensoriais destes produtos e pela estabilidade microbiológica conferida. As propriedades probióticas também foram investigadas. Estudos mais recentes de culturas autóctones têm recebido maior atenção, tendo em conta a procura de culturas isoladas de uma determinada matéria-prima e de uma determinada região. Estas culturas estão sendo estudadas por seu potencial funcional e tecnológico que pode ser aplicado no desenvolvimento de produtos com suas próprias características e denominação de origem. Essas propriedades serão discutidas na presente revisão a fim de destacar o desempenho dessas bactérias e a preocupação com o alto grau de controle sobre o processo de fermentação e padronização do produto final. O uso de culturas autóctones será considerado devido ao incremento de novos estudos de culturas de bactérias lácticas isoladas de leite, de carne e de produtos distintos.

Palavras-chave: bactéria do ácido láctico; cultura autóctone; propriedade tecnológica e funcional; atividade antimicrobiana; produtos lácteos.

\section{INTRODUCTION}

The lactic acid bacteria (LAB) are Gram-positive and non-sporulating bacteria, producing lactic acid as their main fermentation product. Produce large numbers of glycolytic, lipolytic and proteolytic enzymes, which transform the fundamental nutrients from food into compounds with desirable sensory properties (LIMA et al., 2009).

The LAB group works in synergy to contribute to the typical cheese flavour in hard and semi-hard cheeses. It is well accepted that, when cheese is made from raw milk following artisanal procedures, the indigenous microbial content of the raw milk, the cheese-making environment, and the processing equipment all contributes to the sensory quality and the typical features of the final product and, in turn, permit the manufacture of high-value traditional varieties (GARABAL, 2007).

The isolation and study of microorganisms from different foods of animal origin has aimed the identification of strains capable of producing different compounds of interest to the industry. The autochthonous 
LAB derived from sheep's milk or buffalo milk, for example, may be applied in these species dairy production, based on strains already adapted to the raw material source (MORANDI; BRASCA, 2012).

The application of LAB autochthonous in milk also depends on the quality of the raw materials. This is critical for the cultures to perform their functions. The composition of milk and stability of proteolytic, lipolytic and autolytic activity of these organisms are important to determinate the properties of food will be produced (ZDOLEC et al., 2013).

Many of the technological properties of autochthonous starter and non-starter LAB isolated from milk and cheese, are important when planned to exploit the use of these microorganisms in the production, determination and expansion of product characteristics. It is important to consider that different species have different patterns of behavior and activities under industrial conditions (BURNS et al., 2012).

The promotion of its effects on product quality is crucial to the properties of the final product (PIRAINO et al., 2008). The viability of these microorganisms in foods can be affected by factors such as the fermentation conditions, temperature of storage, preservation methods and the inherent characteristics of each species. This is critical for the cultures to perform their functions and are important to determinate the properties of foods (SHAH, 2007).

Recent studies of the effect of adding autochthonous strains as starters or adjunct cultures, on the chemical, microbiological, and sensory characteristics of foods, have demonstrated the beneficial role of these cultures. These results encouraged the use of these cultures in the cheese-making process, for example, in order to better manage and maintain the product regional characteristics produced with indigenous cultures (MANGIA et al., 2014).
Considering the importance of LAB in food and exploitation of new isolates to produce products with protected designation of origin, this review aimed to an analysis of the technological characteristics and functional properties of lactic acid bacteria.

\section{THEORICAL FRAMEWORK}

\section{Lactic acid bacteria (LAB): The group}

This group comprises several genera such as Lactobacillus, Lactococcus, Streptococcus, Pediococcus, Oenococcus, Enterococcus, Vagococcus, and Leuconostoc. The boundaries of the group have been subject of some controversy, but historically the genera Lactobacillus, Leuconostoc, Pediococcus, and Streptococcus form the core of the group (MOZZY et al., 2010). The classification of lactic acid bacteria into different genera is largely based on morphology, mode of glucose fermentation, growth at different temperatures, configuration of the lactic acid produced, ability to grow at high salt concentrations, and acid or alkaline tolerance. Chemotaxonomic markers such as fatty acid composition and constituents of the cell wall are also used in classification. In addition, the present taxonomy relies partly on true phylogenetic relationships, which have been revealed by extensive work on determining rRNA sequences. Some of the newly described genera are most easily determined with oligonucleotide probes, polymerase chain reaction (PCR)-based technologies using these sequences, or direct sequencing of the $16 \mathrm{~S}$ rRNA gene.

LAB exhibit an important role in food fermentation, so the products obtained of their metabolism are characterized by hygienic safety, storage stability and attractive sensory properties. Several properties of LAB such as: acid production in different media and at different temperatures, proteinase and 
peptidase activities, autolysis, production of volatile compounds, resistance to bacteriophages, production of inhibitory compounds are important for their use as starters cultures (ZOTTA et al., 2009). A starter culture can be defined as a microbial preparation of large numbers of cells of at least one microorganism to be added to a raw material to produce a fermented food by accelerating and steering its fermentation process (LEROY; VUYST, 2004).

LAB has different metabolic properties that are directly related to the biochemical events of glycolysis, lipolysis, proteolysis and production of diacetyl, which have a direct importance for milk products. The proteolysis performed by these microorganisms plays an important role in generating peptides and amino acids for bacterial growth and in the formation of metabolites that contribute to flavor formation on fermented products (BELGACEM et al., 2010).

The use of starter cultures is a hallmark of industrial food fermentation and their introduction has been followed by a continuous search to improve them. Examples of desired properties in starter cultures include robustness during manufacturing, fast growth, high biomass yield and product yield and specific organoleptic properties. Currently the study of lactic acid bacteria undergoes a remodeling towards the understanding and improving microbial performance in food fermentation, an approach known as evolutionary engineering (SMID; KLEEREBEZEM, 2014).

\section{Properties of lactic acid bacteria: Proteolytic activity}

The proteolytic system of lactic acid bacteria is very important for the production of fermented milk products (TAKAFUJI et al., 2007).

Besides the importance of proteolytic enzymes in the final organoleptic properties of fermented products, certain LAB strains are further known to be able to release bioactive peptides from proteins, which are thought to have a role in promoting health. The proteolysis resulting from the activity of lactic acid bacteria promotes: the release of volatile aroma compounds, increased meat tenderness, desirable changes in the texture of the product and acceleration of the drying process (LEROY et al., 2006).

LAB are fastidious microorganisms that require an exogenous source of amino acids or peptides, which are provided by the proteolysis of casein, the most abundant protein in milk and the main source of amino acids (SAVIJOK et al., 2006).

In the milk fermentation processes, the proteolytic system of LAB plays the key role enabling these bacteria to grow thereby ensuring a successful fermentation.

Proteolysis is a pre-requisite to $\mathrm{LAB}$ growth and posterior degradation of casein, releasing short peptides and free amino acids. In cheese manufacture, the proteolysis of casein is thought to present a pivotal role because amino acids resulting from proteolysis are the major precursors of specific flavor compounds (SMIT et al., 2005).

In addition to the proteolytic systems of LAB starters there is another important element of cheese manufacture to be considered. This proteolytic activity permits the release of cytoplasmic peptidases into the curd, a prerequisite for bitter flavor formation (SMUKOWSKI et al., 2003).

Savijoki et al. (2006) stated that this proteolytic system allows the survival of these species during the fermentation process. There are also data related to intensive proteolysis on cheese, which can be due to the excessive presence of autochthonous NSLAB (PEREIRA et al., 2008). Madrau et al., (2006) isolated and identified lactic bacteria in buffalo raw milk, according to their 
acidification, growth and proteolytic activity. This selection allowed the preparation of autochthonous starter cultures for inoculation on cheese, because these cultures presented a better adaptation and survival in this dairy product. The selection of lactic bacteria and its use as starter cultures in cheese has been mostly investigated especially on handmade Italian, Portuguese and Spanish cheeses, using raw milk from sheep and with application of autochthonous cultures (NESPOLO, 2009).

\section{Lipolytic activity of lactic acid bacteria}

It is known that the presence of autochthonous LAB in fermented foods interferes with the determination of the sensorial properties of the products. In this context, the lipolytic activity also contributes in promoting important properties. The flavor, which includes taste, aroma, and odor, is one of the most sought properties in foods and its perception depends on the texture of the product. It is the result of a careful balance between volatile and nonvolatile compounds; these coming from the catabolism of carbohydrates, proteins, and lipids from tissue and microbial enzyme activities and chemical reactions, conferring the typically acid taste of fermented foods (SMIT et al. 2005).

The hydrolysis of triglycerides is the main transformation during fat catabolism. The free fatty acids (FFA) liberated contribute to the aroma and flavor of some foods, especially cheese. The intensity of flavor depends not only from FFA concentration, mas also from its distribution between liquid and fat stage, the medium $\mathrm{pH}$, the presence of some cations like $\mathrm{Na}^{+} \mathrm{e} \mathrm{Ca}^{2+}$, and from the resulting products of protein degradation (FADDA et al., 2004).

Yadav et al., (2007) stated that the addition of autochthonous LAB on dairy products contributes to the production of free fatty acids and linoleic acid from milk fat lipolysis, providing a hypolipidemic effect in the host. These bacteria are found in large amounts in lactic foods due to their adaptation capacity in this substrate, which is rich in proteins, lipids and fatty acids (FADDA et al., 2004).

\section{Acid production by lactic acid bacteria}

The food fermentation by LAB is one of the oldest forms of biopreservation practiced by mankind. The raw materials are converted by microorganisms into new products which have acceptable or improved qualities as food. The fermentation by these bacteria is characterized by the accumulation of fatty acids (mainly lactic acid, acetic acid and propionic acid) and by the $\mathrm{pH}$ reduction. The levels and kinds of organic acids produced during this process depend on the species, culture composition and growth conditions (CHERIGUENE et al., 2007).

The acid production is a process considered essential in the manufacture of fermented products and as such, it is common to add fermentable carbohydrates to the food mass, always considering the microbiota that will utilize them and the final products generated. The important aspect of acidification is its contribution to the development of the sensorial properties of fermented foods. The expected functions of the autochthonous starter cultures are the rapid acidification of the prepared raw materials and the development of sensorial characteristics in the final products (LEROY et al., 2006).

The use of alternative techniques such as acidification with lactic acid addition for the manufacture of mozzarella cheese from buffalo milk does not discard the traditional fermentation by LAB. This because the use of more than one lactic bacteria or association between different isolates may 
promote an increase in the production of the organoleptic properties of the products, by production of different types of organic acids (CHERIGUENE et al., 2007). During milk fermentation, the production of acid by LAB reduces medium $\mathrm{pH}$, which facilitates serum separation by rennet action, thus reducing the moisture content. Therefore, low pH and low humidity retard the development of undesirable microorganisms. Due to fermentation process, changes in the $\mathrm{pH}$ of mozzarella cheese from buffalo milk persist in the storage time under refrigeration (CORTEZ et al., 2008).

Studies demonstrate the ability of autochthonous LAB strains in producing distinct aroma as compared to those produced by commercial starter cultures. Some strains can show low acidifying activity and, this way, must be combined with industrial strains to prepare starter cultures with defined strains. The reduction of $\mathrm{pH}$ at the beginning of fermentation is extremely important for cheese production, since it is essential for coagulation and reduction of contaminating microorganisms (AYAD et al., 2004).

Despite the rapid acidification required to reduce microbiological hazards caused by pathogenic bacteria in fermented products and matured, some microorganisms can survive in foods such as Staphylococcus aureus, Escherichia coli, Salmonella and Listeria monocytogenes (LEROY et al., 2006). It is believed that the low $\mathrm{pH}$ causes extracellular acidification of the cytoplasm and reduces the metabolic activity of the cell, without causing the death of these microorganisms (AMMOR; MAYO, 2007).

\section{Homofermentative and heterofermenta- tive lactic acid bacteria}

The main characteristic of LAB metabolism is the efficient fermentations of substrates, associated to phosphorylation at substrate level (MOZZY et al., 2010). The route on which the hexoses are metabolized by lactic acid bacteria divide them into two groups: homofermentative and heterofermentative (RIBEIRO et al., 2013).

Homofermentative bacteria metabolize carbohydrates through Embden-MeyerhofParnas pathway generating two lactate molecules per glucose molecule. On the homofermentative LAB, initially occurs the phosphorylation of glucose and lately of fructose-6-phosphate, originating fructose1-6-diphosphate, which is degraded through fructose-1,6-diphosphate-aldolase in two interchangeable trioses, dihydroxyacetone phosphate and glyceraldehyde-3-phosphate. The last is oxidated to 1,3-diphosphoglycerate which, by a chain reaction involving a kinase, mutase and enolase, originates pyruvate (HUERTAS, 2010).

Because the homofermentative LAB do not have pyruvate-decarboxylase, they transfer the $\mathrm{H}^{+}$generated by the action of phosphotyrosine-dehydrogenase to pyruvic acid with the support of Nicotinamide Adenine Dinucleotide (NAD), and then transforms it in lactic acid. All members of the genera Pediococcus, Streptococcus, Lactococcus and Enterococcus are homofermentative, as well as some Lactobacillus (MOZZY et al., 2010).

The heterofermentative LAB can be classified as facultative or obligatory heterofermentatives, according to the fermentation pathway. They utilize $1 \mathrm{~mol}$ of glucose to form $1 \mathrm{~mol}$ of lactic acid, $1 \mathrm{~mol}$ of ethanol and $1 \mathrm{~mol}$ of $\mathrm{CO}_{2}$ (HUERTAS, 2010). The facultative heterofermentative species metabolizes hexoses by glycolytic EmbdenMeyerhof pathway, but are also capable of metabolizing pentoses and other substances through a 6-phosphoketolase. The obligated heterofermentative species uses only the phosphoketolase pathway to metabolize sugars, and their final fermentation products are mainly lactic acid, acetic acid, ethanol and $\mathrm{CO}_{2}$. The 
genera belonging to heterofermentative LAB group are: Leuconostoc, Oenococcus, and some Lactobacillus.

The knowledge of the fermentative characteristics of the required species is important to its application on food, according to what is expected from the final product. Firstly, the food itself from which the culture was isolated would be the best choice for its application, due to the easier adaptation and production of substances of interest (HUERTAS, 2010).

\section{Importance of research of autochthonous cultures}

Raw milk constitutes a good source of lactic bacteria likely to be utilized by the dairy industry because they are already well adapted to weather and raw material conditions (NESPOLO, 2009).

The food autochthonous microorganisms include, endogenous and contaminating species, resulting from the hygienic processes during their production. Strains capable of producing great variety of compounds with antibacterial activity that reduces survival or inhibits the growth of pathogens can be included. The raw milk autochthonous microorganisms greatly interferes on the development of pathogenic and spoilage microorganisms, especially when present in high concentrations (BAGGE-RAVEN et al., 2003).

Isolation of autochthonous LAB from cheese manufactured without the addition of commercial starter culture is the basis for selection of new strains with desirable properties. The activity of bacteria naturally present in the milk is rather controlled and predictable, which results in more uniform sensory characteristics and composition of the product (SUSKOVIC et al., 2010),

The use of commercial starter cultures in fresh cheese production from pasteurized milk results in the loss of typical characteristics of artisanal cheese, due to the replacement of the complex native microbiota by a defined starter culture (PIRAINO et al., 2008).

Hence, the utilization of autochthonous starter cultures consisting of LAB isolated from traditionally produced fresh soft cheese. Therefore it is necessary to prove the technological and functional benefits of these cultures, which guarantee the improvement of product quality and, at the same time, preservation of the characteristics that define the identity of the traditional cheese. When applied as starter cultures on the production of dairy or fermentated products, autochthonous LAB are important to provide specific sensorial characteristics of each product (GONZÁLEZ et al., 2007).

Modern starter cultures have been developed from the practice of retaining small quantities of whey or cream from the successful manufacture of a fermented product on a previous day and using this as the inoculum or starter for the preceding day's production. This practice has been called by various names but the term 'back-slopping' is used broadly (MULLAN, 2011). Spontaneous fermentation was optimized through back-slopping, i.e., inoculation of the raw material with a small quantity of a previously performed successful fermentation. Hence, backs-lopping results in dominance of the best adapted strains. It represents a way of using a selected starter culture to shorten the fermentation process and to reduce the risk of fermentation failure (RATTANACHAIKUNSOPON; PHUMKHACHORN, 2010).

The direct addition of selected starter cultures to raw materials has been a breakthrough in the processing of fermented foods, resulting in a high degree of control over the fermentation process and standardization of the final product (LEROY; VUYST, 2004).

Progress in molecular biology techniques has led to a pool of information on the natural microbial population. This can help to 
prevent the loss of microbial biodiversity in typical foods (PSONI et al., 2004). Moreover, these data may be a helpful guideline for the selection of promising autochthonous LAB strains as starters for specific flavour formation or as protective cultures with bacteriocinogenic activity in fermented dairy products (BEGANOVIC et al., 2001).

In the last years, most studies have been made to isolate and identify autochthonous LAB both from raw milk and cheese produced without the addition of any starter cultures (RANDAZZO et al., 2009). The endogenous microbial population present on raw milk can be preserved and selected during cheese production (MADRAU et al., 2006).

Nespolo (2009) on her study isolated and applied autochthonous LAB as starter cultures to the production of sheep's cheese. The combination of the isolates demonstrated to be adequate on the Fascal cheese production under experimental conditions. Cheddar cheese produced with endogenous cultures that included Lactobacillus showed significantly higher hardness, elasticity and fracturability values. The utilization of Lb. bulgaricus UL12 strain combined to another bacteriocinogenic strain caused an increase in cheese proteolysis and an improvement on Cheddar cheese texture (SALLAMI et al., 2004).

Biscola et al., (2014) observed that L. lactis 69 did not affect the counts and diversity of lactic acid bacteria during manufacturing and storage of charqui, but influenced negatively the populations of halotolerant microorganisms, reducing the spoilage potential. The majority of tested virulence genes were absent, evidencing the safety and potential technological application of this strain as an additional hurdle to inhibit undesirable microbial growth in this and similar fermented meat products.

Quero et al., (2014) selected autochthonous multiple strain culture (AMSC) composed of one Lb. bulgaricus, one $L b$. paracasei and one $S$. thermophilus strain. The cultures were applied for the pilotscale production of traditional Matsoni, and resulted the best in terms of enhanced shelflife (one month), sensorial and nutritional quality without altering its overall typical quality.

Several works have been done with not yet identified LAB. Isolations have been made - from different products, evaluating important properties of isolates (See Table 1). The autochthonous LAB isolated in food must be innocuous to consumers, where they are applied. For this, there are criteria recommended by Food and Agriculture Organization (FAO) and World Health Organization (WHO) for evaluating microorganisms utilized in food (MORANDI; BRASCA, 2012). The European Food Safety Authority (EFSA) proposed an evaluation list for microorganisms applied on food, similar to the already proposed list by the Food and Drug Administration (FDA), with the statute Qualified Presumption of Safety (QPS). This proposition is based on four principles: 1) taxonomy; 2) familiarity; 3) pathogenicity - if the group has pathogens and 4) function - if the microorganisms enter in the food chain and if they are used in the fabrication of other products. According to these criteria the genera Lactobacillus and Lactococcus have QPS status, contrary to the genus Enterococcus due to the actual scientific knowledge about the existence of virulent strains of this genus. For Enterococcus, the decision about its safety is made for each case, based on the research of virulent factors for each strain (EFSA, 2011).

\section{FINAL THOUGHTS}

Numerous researches demonstrated that the use of adjunct or starter cultures allows to obtain foods with organoleptic characteristics expected and represent an 
Table 1 - New cultures of lactic acid bacteria isolated from different environments and their benefits in the production of new products

\begin{tabular}{|c|c|c|c|}
\hline Autochthonous cultures & Product & Benefits & Authors \\
\hline $\begin{array}{l}\text { Lb. plantarum, Lb. fermentum, } \\
\text { and } \\
\text { Lb. paracasei subsp. paracasei }\end{array}$ & $\begin{array}{l}\text { Turkish lactic } \\
\text { acid-fermented } \\
\text { beverage }\end{array}$ & $\begin{array}{l}\text { Important production } \\
\text { of organic acids } \\
\text { and the best cellular } \\
\text { growth. }\end{array}$ & $\begin{array}{l}\text { Tangüler; } \\
\text { Erten, } \\
2013\end{array}$ \\
\hline $\begin{array}{l}\text { Lactobacillus } \\
\text { and } \\
\text { Staphylococcus }\end{array}$ & Salsiccia Sarda & $\begin{array}{l}\text { Rapid acidification, } \\
\text { reduced the number } \\
\text { of spoilage } \\
\text { microorganisms }\end{array}$ & $\begin{array}{l}\text { Mangia } \\
\text { et al.,2013 }\end{array}$ \\
\hline $\begin{array}{l}\text { Lac. lactis subsp. lactis, } \\
\text { L. plantarum } \\
\text { and Leu. mesenteroides subsp. } \\
\text { mesenteroides }\end{array}$ & Cheeses & $\begin{array}{l}\text { Higher scores for } \\
\text { sensory attributes, } \\
\text { especially for aroma }\end{array}$ & $\begin{array}{l}\text { González; } \\
\text { Zárate, } \\
2012\end{array}$ \\
\hline $\begin{array}{l}\text { Pediococcus acidilactici } \\
\text { and } \\
\text { Staphylococcus vitulus }\end{array}$ & $\begin{array}{l}\text { Salchichón and } \\
\text { chorizo }\end{array}$ & $\begin{array}{l}\text { Reducing } \\
\text { Enterobacteriacea } \\
\text { proliferation at the } \\
\text { beginning of the } \\
\text { ripening process. } \\
\text { Effect against food- } \\
\text { borne pathogens. }\end{array}$ & $\begin{array}{l}\text { Casquete } \\
\text { et al., } 2012\end{array}$ \\
\hline $\begin{array}{l}\text { Lactobacillus sakei } \\
\text { and } \\
\text { Staphylococcus equorum }\end{array}$ & $\begin{array}{l}\text { Fermented } \\
\text { sausages }\end{array}$ & $\begin{array}{l}\text { The final product with } \\
\text { better microbiological } \\
\text { and chemical-physical } \\
\text { features and a positive } \\
\text { effect on flavor and } \\
\text { aroma compounds } \\
\text { formation. }\end{array}$ & $\begin{array}{l}\text { Bonomo } \\
\text { et al., } 2011\end{array}$ \\
\hline $\begin{array}{l}\text { Streptococcus thermophilus, } \\
\text { Lactobacillus delbrueckii } \\
\text { subsp. lactis } \\
\text { and } \\
\text { Lactobacillus helveticus }\end{array}$ & $\begin{array}{l}\text { Pecorino } \\
\text { Romano } \\
\text { cheese }\end{array}$ & $\begin{array}{l}\text { Improve the physico- } \\
\text { chemical features of } \\
\text { Pecorino Romano } \\
\text { while preserving its } \\
\text { tipicity. }\end{array}$ & $\begin{array}{l}\text { Mangia } \\
\text { et al., } 2011\end{array}$ \\
\hline
\end{tabular}


efficient tool to standardize the production process improving the safety and quality and preserving the typical character of the products.

Microbial starter cultures are essential for consistent product quality and functional properties such as flavor, texture, $\mathrm{pH}$ or the alcohol content of various fermented foods. The study and understanding of the actual performance of different isolates of lactic acid bacteria, provides information for selecting cultures with desired properties, meeting the demands of consumers who increasingly require differentiated products with identity and quality standards.

Strain improvement programs to achieve desired properties in starter cultures are diverse, but developments in next-generation sequencing lead to an increased interest in evolutionary engineering of desired phenotypes. Furthermore the analysis of evolved phenotypes and possibilities with complex consortia are highlighted. Studies carried out with mainly yeast and autochthonous lactic acid bacteria demonstrate the power of these cultures to deliver strains with novel phenotypes as well as to determine news properties to the products.

Lactic acid bacteria have a long history in human cultural traditions. Until recently these organisms have been performing simple and basically similar tasks, differing only in scale and precision, as they did thousands of years ago. Novel applications based on a better understanding of the potential of lactic acid bacteria in biotechnology, and especially of their role in promoting health and combating disease, are emerging. The potential significance more than justifies multidisciplinary research in this field, with targets in both food and feed development and promoting human and animal health and wellbeing as well as developing new products.

New studies and research with autochthonous cultures allow knowledge for a more rational use of $\mathrm{LAB}$ species not only in traditional fermentations but also in novel food bioprocessing, as probiotic, with functional and technological applications.

The detailed characterization of autochthonous LAB is indispensable for a possible application of these strains in the food, since it is of great value for future commercialization, given the potential benefits to health and well-being of the consumer. Thus, they can be used properly to secure the sensorial characteristics and food safety in milk and dairy products, and other products.

\section{ACKNOWLEDGMENT}

This review article is the result of work by researchers from the Federal University of Pelotas and the Federal University of Rio Grande do Sul.

\section{REFERENCES}

AMMOR, M. S.; MAYO, B. Selection criteria for lactic acid bacteria to be used as functional starter cultures in dry sausage production: an update. Meat Science, v. 76, n. 1, p. 138146, 2007.

AYAD, E. H. E. et al. Application of wild starter cultures for flavour development in pilot plant cheese making. International Dairy Journal, v. 10, n. 3, p. 169-179, 2004.

BAGGE-RAVN, D. Y. N. G. et al. The microbial ecology of processing equipment in different fish industries analysis of the microflora during processing and following cleaning and disinfection. International Journal of Food Microbiology, v. 87, n. 3, p. 239-250, 2003.

BEGANOVIC, J. et al. Improved sauerkraut production with probiotic strain Lactobacillus plantarum L4 and Leuconostoc mesenteroides 
LMG 7954. Journal of Food Science, v. 76, n. 2, p. 124-129, 2011.

BELGACEM, Z. B. et al. Antimicrobial activity, safety aspects, and some technological properties of bacteriocinogenic Enterococcus faecium from artesanal Tunisian fermented meat. Food Control, v. 21, n. 4, p. 462-470, 2010.

BISCOLA, V. et al. Effect of autochthonous bacteriocin-producing Lactococcus lactis on bacterial population dynamics and growth of halotolerant bacteria in Brazilian charqui. Food Microbiology, v. 44, p. 296-301, december 2014

BONOMO, M. G.; RICCIARDI, A.; SALZANO, G. Influence of autochthonous starter cultures on microbial dynamics and chemical-physical features of traditional fermented sausages of Basilicata region. World Journal of Microbiology and Biotechnology, v. 27, n. 1, p. 137-146, 2011.

BURNS, P. et al. Technological and probiotic role of adjunct cultures of non-starter lactobacilli in soft cheeses. Food Microbiology, v. 30, n. 1, p. 45-50, 2012.

CASQUETE, R. et al. Microbiological quality of salchichón and chorizo, traditional Iberian dry-fermented sausages from two different industries, inoculated with autochthonous starter cultures. Food Control, v. 24, n. 1-2, p. 191-198, 2012.

CORTEZ, M. A. S. et al. Effect of $\mathrm{pH}$ on characteristics of low-moisture Mozzarella cheese during refrigerated storage. Journal of Food Science, v. 73, n. 9, p. 443-448, 2008.

CHERIGUENE, A. et al. Enumeration and identification of lactic microflora in Algerian goats' milk. African Journal of Biotechnology, v. 6, n. 15, p. 1854-1861, 2007.
EUROPEAN FOOD SAFETY AUTHORITY (EFSA). Scientific Opinion on the maintenance of the list of QPS biological agents intentionally added to food and feed. EFSA Journal, v. 9, n. 12, p. 2497- 2579, 2011.

FADDA, M. E. et al. Occurrence and characterization of yeasts isolated from artisanal Fiore Sardo cheese. International Journal of Food Microbiology, v. 95, n. 1, p. 51-59, 2004.

GARABAL, J. I. Biodiversity and the survival of autochthonous fermented products. International Microbiology, v. 10, n. 1, p. 1-3, 2007.

GONZÁLEZ, L.; ZÁRATE, V. Influence of an autochthonous starter culture and a commercial starter on the characteristics of Tenerife pasteurised goats' milk cheese. International Journal of Dairy Technology, v. 65 , n. 4, p. 542-547, 2012.

GONZÁLEZ, L.; SANDOVAL, H.; SACRISTÁN, N. Identification of lactic acid bacteria isolated from Genestoso cheese throughout ripening and study of their antimicrobial activity. Food Control, v. 18, n. 6, p. 716-722, 2007.

HUERTAS, R. A. P. Bacterias Acido Lácticas: Papel funcional en los alimentos. Revista Biotecnología En El Sector Agropecuario Y Agroindustrial, v. 8, n. 1, p. 93-105, 2010.

LEROY, F.; DE VUYST, L. Lactic acid bacteria as functional starter cultures for the food fermentation industry. Trends in Food Science and Technology, v. 15, n. 2, p. 6778, 2004.

LEROY, F.; VERLUYETEN, J.; DE VUYST, L. Functional meat starter cultures for improved sausage fermentation. International 
Journal of Food Microbiology, v. 106, n. 3, p. $270-285,2006$.

LIMA, C. Bactérias do ácido láctico e leveduras associadas com o queijo-de-minas artesanal produzido na região da Serra do Salitre, Minas Gerais. Arquivo Brasileiro de Medicina Veterinária e Zootecnia, v. 61, n. 1, p. 266-272, 2009.

MADRAU, M. A. et al. Employment of autochthonous microflora in Pecorino Sardo cheese manufacturing and evolution of physicochemical parameters during ripening. International Dairy Journal, v. 16, n. 8, p. 876-885, 2006.

MANGIA, N. P. et al. Microbiological and physicochemical properties of pecorino romano cheese produced using a selected starter culture. Journal of Agricultural Science and Technology, v. 13, n. 4, p. 585-600, 2011.

MANGIA, N. P. et al. Effect of the use of autochthonous Lactobacillus curvatus, Lactobacillus plantarum and Staphylococcus xylosus strains on microbiological and biochemical properties of the Sardinian fermented sausage. European Food Research and Technology, v. 236, n. 3, p. 557-566, 2013.

MANGIA, N. P. et al. Influence of autochthonous lactic acid bacteria and enzymatic yeast extracts on the microbiological, biochemical and sensorial properties of Lben generic products. Journal of Dairy Research, v. 81, n. 2, p. 193-201, 2014.

MORANDI, S.; BRASCA, M. Safety aspects, genetic diversity and technological characterization of wild-type Streptococcus thermophilus strains isolated from north Italian traditional cheeses. Food Control, v. 23, n. 1, p. 203-209, 2012.
MOZZY, F. F.; RAYA, R. R.; VIGNOLO, G. $\mathrm{M}$. Biotechnology of lactic acid bacteria novel applications. $1^{\mathrm{a}}$ ed. Ames:WileyBlackwell, 2010. 408p.

MULLAN, W. M. A. Microbiology of starter cultures. 2011. Available at: <http:// www.dairyscience.info/index.php/cheesestarters/49-cheese-starters.html>. Accessed on: Jan. 24th 2013.

NESPOLO, C. R. Características microbiológicas e físico-químicas durante o processamento de queijo de leite de ovelha. 2009. 215f. Tese (Doutorado em Microbiologia Agrícola e do Ambiente) - Universidade Federal do Rio Grande do Sul, Rio Grande do Sul, 2009.

PEREIRA, C. I. How three adventitious lactic acid bacteria affect proteolysis and organic acid production in model Portuguese cheeses manufactured from several milk sources and two alternative coagulants. Journal of Dairy Science, v. 93, n. 4, p. 1335-1344, 2008.

PIRAINO, P. et al. Acid production, proteolysis, autolytic and inhibitory properties of lactic acid bacteria isolated from pasta filata cheeses: A multivariate screening study. International Dairy Journal, v. 18, n. 1, p. 81-92, 2008

PSONI, L. et al. Genotypic and phenotypic diversity of Lactococcus lactis isolates from Batzos, a Greek PDO raw goat milk cheese. International Journal of Food Microbiology, v. 114, n. 2, p. 211-220, 2007.

QUERO, G. M. et al. Microbiological, physico-chemical, nutritional and sensory characterization of traditional Matsoni: Selection and use of autochthonous multiple strain cultures to extend its shelf-life. Food Microbiology, v. 38, p. 179-191, april 2014. 
RAT TAN A C H A I K UN S O P O N, P.; PHUMKHACHORN, P. Lactic acid bacteria: their antimicrobial compounds and their uses in food production. Annals of Biological Research, vol. 1, n. 4, p. 218-228, 2010 .

RANDAZZO, C. L.; CAGGIA, C.; NEVIANI, E. Application of molecular approaches to study lactic acid bacteria in artisanal cheeses. Journal of Microbiological Methods, v. 78, n. 1, p. 1-9, 2009.

RIBEIRO, S. C. et al. Technological properties of bacteriocin-producing lactic acid bacteria isolated from Pico cheese an artisanal cow's milk cheese. Journal of Applied Microbiology, v. 116, n. 3, p. 573-585, 2013.

SALLAMI, L.; KHEADR, E. E., VUILLEMARD, J. C. Impact of autolytic, proteolytic, and nisin-producing adjunct cultures on biochemical and textural properties of cheddar cheese. Journal of Dairy Science, v. 87 , n. 6 , p. 1585-1594, 2004.

SAVIJOKI, K.; INGMER, H.; VARMANEN, P. Proteolytic systems of lactic acid bacteria. Applied Microbiology and Biotechnology, v. 71, n. 4, p. 394-406, 2006.

SHAH, N. P. Funcional cultures and health benefits. International Dairy Journal, v. 17, n. 11, p. $1262-1277$.

SMID, E. J.; KLEEREBEZEM, M. Production of aroma compounds in lactic fermentations. Annual Review of Food Science and Technology, v. 5, p. 313-326, february 2014.

SMIT, G.; SMIT, B. A.; ENGELS, W. J. M. Flavour formation by lactic acid bacteria and biochemical flavour profiling of cheese products. FEMS Microbiology Reviews, v. 29, n. 3, p. 591-610, 2005.

SMUKOWSKI, M. et al. Impact of cheese defects on U.S. graded cheeses. Journal of Dairy Science, v. 86, n. 1, p. 364, 2003.

SUSKOVIC, J. et al. Antimicrobial activity The most important property of probiotic and starter lactic acid bacteria. Food Technology and Biotechnology, v. 48, n. 3, p. 296-307, 2010 .

TAKAFUJI, S. et al. Proteolytic enzymes of lactic acid bacteria. Developments in Food Science, v. 37, p. 753-767, 1995.

TANGÜLER, H.; ERTEN, H. Selection of potential autochthonous starter cultures from shalgam, a traditional Turkish lactic acidfermented beverage. Turkish Journal of Agricultural Forestry, v. 37, n. 2, p. 1-9, 2013.

YADAV, H.; JAIN, S.; SINHA, P. R. Production of free fatty acids and conjugated linoleic acid in probiotic dahi containing Lactobacillus acidophilus and Lactobacillus casei during fermentation and storage. International of Dairy Journal, v. 17, n. 8, p. 1006-1010, 2007.

ZOTTA, T.; PARENTE, E.; RICCIARDI, A. Viability staining and detection of metabolic activity of sourdough lactic acid bacteria under stress conditions. World Journal of Microbiology and Biotechnology, v. 25, n. 6, p. 1119-1124, 2009.

ZDOLEC, N. et al. Selection and application of autochthonous functional starter cultures in traditional Croatian fermented sausages. International Food Research Journal, v. 20, n. 1, p. 1-6, 2013. 